\title{
JOURNEY WOMEN: WOMEN'S RESILIENCE AND TRANSFORMATION IN QASHAM BALATA'S RUNAWAY TO NOWHERE
}

\author{
LOLAV M. HASSAN ALHAMID \\ Dept. Of English, College Of Languages, University Of Duhok, Kurdistan Region-Iraq
}

(Received: December 16, 2017; Accepted for Publication: April 12, 2018)

\begin{abstract}
This study explores the developmental processes of a number of female characters in Qasham Balata's Runaway to Nowhere (2010) which depicts the implications of a series of historical incidents on Kurdish women's experiences as expressive of the collective Kurdish socio-political experience in Iraq. Writing from a feminist perspective, Balata focuses on the maturation of Nareen, the protagonist, and portrays her transformation from a hopeless victim to a well-informed social activist. By cataloguing the experiences of Nareen and other female characters in the period immediately before and during the Persian Gulf War 19901991, the Kurdish popular Uprising, the Kurds' subsequent mass-exodus to the Turkish and Iranian borders, and the creation of a de-facto Kurdish state in the north of Iraq, Balata shows that such destructive events represent shifting phases in the maturation processes of the lives of Kurdish women who learn how to survive these events and aspire to make a positive change, at least on personal levels. In the exploration of Nareen's determination as well as her resilience and eventual emancipation, Rita Felski's argument of modern writing by women as a medium through which female political identities and collective consciousness are constructed and represented are adopted to discuss the structural and thematic properties of the text.
\end{abstract}

KEYWORDS: Violence, Kurdish Women's Transformation, Feminist Bildungsroman, Solidarity, and Public Sphere.

\section{RUNAWAY TO NOWHERE: AN INTRODUCTION}

B alata $^{1}$ wrote and published Runaway to Nowhere, her first and only novel so far, in English confirming that a main reason for writing it has been to show the world the reality of the Kurdish historical and socio-political situation, at least in Iraqi Kurdistan (Balata, 2016, Personal Interview). Balata's text is an influential illustration of the lively linguistic debate within Kurdish studies which regards the inclusion or exclusion of literary texts by writers of Kurdish origins written in other languages. In other words, the question of whether language should be considered a measure by which to determine the identity of the text and its inclusion or exclusion from the Kurdish literary discourses. Balata believes that "language cannot be used to determine the identity of a literary text. It is the spirit of the text, that is, the culture, the social manners and traditions represented that should be used as measures to define a literary text" (Ibid.)
Balata further describes her novel as a kind of tribute and an expression of her feelings of responsibility to record and depict some of the miserable experiences of the Kurdish people and the atrocities and violence imposed on them, particularly Kurdish women, who remain the recipients of the worst forms of violence and oppression (Ibid). War and armed conflicts turn women of the enemy into direct targets of such brutal war-related acts as deportation, mass-rape, emotional and bodily abuse and mass-murder throughout the conflict-zone. ${ }^{2}$ For almost a decade, Kurdish women in this conflict zone were exposed to both an internal war waged by the patriarchal society and an external war aimed at the suppression and elimination of the Kurdish national and cultural identity by the Iraqi regime. On the internal level, they were subjected to various forms of domestic abuse, forced marriages, polygamy, sexual violence, honour-killing and a gendered division of labour. Moreover, as a part of the Kurdish nation, women were exposed to systematic acts of genocide and ethnic, cultural and linguistic assimilation. 
Runaway to Nowhere depicts many of these forms of violence and presents characters' growing tactics of resistance and survival dramatized against the background of a destructive war. The novel, moreover, presents, in a combination of first and third-person narration, the story of Nareen's development from a simple woman having no control over her life and decisions to a mature woman with a good degree of freedom and independence unavailable to most women in the Kurdish society of the nineties and early 2000s. An effective critical explication of the novel needs to follow the two principal storylines: Nareen's physical journey towards the Turkish borders prompted by her urge to survive and save her brother and her emotional journey represented by her transformation from a state of passivity and submission to a state of resistance and activism. Nareen, who becomes the reluctant chronicler of the Kurds' mass exodus to the mountains, tells of the way Kurdish people have to wait and contemplate fluctuating political circumstances while suffering severe economic sanctions, threats of wars and constant dangerous air raids by the Iraqi military. Her detailed chronicle of the outbreak and collapse of the Kurdish 1990 Uprising and the deteriorating conditions of the Kurdish people running for their lives is accompanied by a close description of her love for Karwan and the way they are separated as Karwan chooses to stay and defend the city against the Iraqi army. Once in the refugee camp, Nareen befriends a number of women whose solidarity soon becomes a form of resistance signified by their refusal to succumb to destructive forces most prominently being the discriminative authority of the men in their families. Although she loses Karwan, who is killed defending the city, Nareen's experiences in the camp inspires her to commit to social activism as she works, by the end of the novel, in a centre for women's advancement and protection.

In her influential reflection of the novel, Kani Xulam of the American Kurdish Information Network (AKIN) describes the novel as a book about love, war, and the hopelessness of the Kurdish woman. Xulam adds that the novel is:

About the cruelty of the Kurdish man. It is about the brutality of Arabs. It is about the fickleness of 'Great Powers.' It is about the dearth of virtue. It is about the absence of honour.
And yes, it is also about the transience of freedom. (Kurdistan Commentary, https://kurdistancommentary.wordpress.com/2011 /03/02/runaway-to-nowhere/)

By incorporating feminist issues of social inequality, domestic abuse, violence against women, and women's socio-political activism into broader questions of wars, political antagonism, nationalism and national struggle for liberation, the novel affirms the significant and problematic interplay between feminism and nationalism in the Kurdish context. Adopting this interplay, Balata gives a national sense and meaning to characters' personal experiences. For example, many readers may see Runaway to Nowhere as the love story between Nareen and Karwan, but in the preface to the novel, Balata identifies the national dimension of her work by confirming that "their love story crosses the path of the first Gulf war and all the subsequent events" (Balata, 2010: 11) ${ }^{3}$

Accordingly, the novel depicts feminist themes alongside the broader questions of Kurdish social norms and national struggle. Taking this interrelation between Kurdish women's issues and social and national questions throughout, the study explores the ways in which Balata, as a Kurdish woman writer, represents marginalized cultures and silenced groups in times of conflict and peace in her work and produces for the first time in Kurdish literature a feminist sense of representation through paying strict attention to the experiences of various female characters that stand for the majority of Kurdish women in society. Moreover, Balata problematizes the tradition-bound image of women by creating counter-public discourses that accommodate their socio-political roles and participations. Exploring these key issues, the article answers such questions as how does Balata portray women's oppression? How do the social and historical contexts shape women's transformation? And by exploring their socio-political roles as portrayed in the novel, how is women's resilience represented? It is important to mention that these questions are now urgently on the agendas of scholars from contexts as diverse as war and peace studies and the cultural and literary domains of Kurdish studies. 


\section{REPRESENTATION OF NAREEN'S DEVELOPMENT THROUGH GENERIC CONSTRUCTION}

The term journeywoman used in the title of the study is inspired by the African American female writer Audre Lorde's employment of the expression in the dedication of her 1982 autobiography entitled Zami: A New Spelling of My Name: "To whom do I owe the woman I have become? To the journeywoman pieces of myself" (Lorde, 1982: 5). The term is utilised here to discuss and explore Nareen's developmental trajectories through different rather complicated stages portrayed throughout the book. To start with its basic definition, the term journeywoman, as the female equivalent of a journeyman, refers to an individual who "has fully served an apprenticeship in a trade or craft and is a qualified worker in another's employ" (Answers," American Heritage Dictionary, [accessed July, 11, 2014]). In Writing the Subject: Bildung and the African American Text, Gunilla Theander Kester discusses the developmental trajectories of the life of John Wolfgang von Goethe's protagonist in his Wilhelm Meister and illustrates that there are "three characteristic steps in the maturation process of Goethe's young hero-Apprenticeship, Journeymanship, [and] Mastery" (Kester, 1997: 50). Balata's novel eloquently traces the process of maturation of a Kurdish girl focusing on her attempts to make sense of her cruel war-torn world. Though not as clear as it is with Goethe's protagonist, Nareen does move going through the three steps mentioned in Kester's discussion of Wilhelm Meister. Nareen spends her childhood in a very traditional Kurdish family whose members safely believe in and share the values of their Kurdish society. Nareen is tired of her familial and social restrictions and believes "in the possibility of a more equitable society, and a better world" (31). Apprenticed in a highly patriarchal society, Nareen manages to move to the second step, the journeywomanship. This step in Nareen's journey takes place when she is forced into migration along with her family and millions of Kurds to the frozen mountains of Turkey to escape the approaching army of Saddam Hussein during the Kurds' 1991 mass-migration. Though Nareen manages to process from the first stage into the second stage represented by journeywomanship in
Kester's discussion, the third stage, the mastery, remains ambiguous and unspecified as Nareen must first overcome the traditional and patriarchal values of her world in order for her to achieve mastery.

The three basic steps in Kester's discussion of the maturation process in Goethe's Wilhelm Meister are apparently repeated in Runaway to Nowhere. Technically, these three steps help Balata in first, giving a form of authority and mastery to her protagonist noticeable primarily in Nareen's mastery as a focal character on whom the "audience is meant to place the majority of their interest and attention. He or she is almost always also the protagonist of the story" (Definitions," English Encyclopaedia, accessed July, $\quad 10, \quad 2014$, http://www.encyclo.co.uk/define/Focal\%20charact er). Second, employing these three steps helps the writer in tracking the process of her protagonist's development and, hence, locating her work within the traditional forms of self-writing or autobiographically-structured accounts and the Bildungsroman albeit with certain modifications and reconfigurations that will be explained in this part of the article. The Bildungsroman also known as a coming-out story or a novel of formation focuses on "the spiritual and intellectual maturation of its protagonist" (Boes, 2012: 1). In her study "Social Mobility in the English Bildungsroman," Kester, provides a fuller description of the genre in respect to the process through which the protagonist goes:

The genre focuses on the development of a single individual within a particular social world...it is the history of this individual from childhood up to a point at which the development or unfolding of his or her character is achieved; in other words it is the story of apprenticeship rather than a life history. (Kester, 1997: 52)

Although Balata started her literary career in the Western world, specifically in the USA, it is not as important to ask whether she consciously sets her novel within the context of the Bildungsroman as it is to investigate the ways she tries to differentiate and separate her work as a contemporary feminist writing from the traditional bourgeois realist fiction. If "genres are essentially literary institutions, or social contracts between a writer and a specific public, whose function is to specify the proper use of a particular cultural artefact," (Felski, 1989: 85) then, Balata must be 
seeking to consider not only the formal structure of her text, but also the subject matter she addresses and the ideology of her readers. Central to contemporary feminist fiction, as a medium of 'self-exploration' and social and cultural criticism, is the construction of a form, i.e., a genre that best addresses and represents women's changing needs and interests. Discussing the social meanings and functions of feminist literature, the feminist theorist and literary critic Rita Felski argues in Beyond Feminist Aesthetics: Feminist Literature and Social Change that: "Because many women writers of the last twenty years have been concerned with addressing urgent political issues and rewriting the story of women's lives, they have frequently chosen to employ realist forms" (Ibid.).

The realist forms in Felski's discussion involve two main categories: the 'confession' novels and the novels of 'self-discovery' that she further divides into two groups: the novel of 'awakening' and a 'feminist Bildungsroman.' Though these forms are modifications and variations of the existing genres of autobiography and the Bildungsroman, Felski generates this category of self-discovery "to designate all those texts by women writers which trace a clear narrative of female emancipation through separation from a male-defined context" (Ibid.). As a text written by a woman about a female protagonist and received within the context of feminist literature, Runaway to Nowhere contains, if not based mainly on implicit autobiographical elements. The power of the text, however, does not only lie on the autobiographical voice, but also on its description of the tensions and interactions between the categories of the personal and the political as represented throughout the text. It is, thus, important in any reading of autobiography or the Bildungsroman as a novel of female maturation to take into account questions of ethnicity and sexuality. Elucidating the social significance of feminist writing including narratives of female emancipation and the Bildungsroman, Felski writes:

On the one hand, it is autobiographical, exploring woman's changing perception of self; on the other, this examination of subjectivity acquires a representative significance through the superimposition of trans-subjective pattern of meaning, a narrative of emancipation derived from the political ideology of feminism. (Ibid.)
Illustrating the intersection of the coming-out story or the Bildungsroman with the 'life-writing' forms and narratives that cannot fit easily within its definition such as narratives of trauma, illness, death, marginality and enforced silence, Stella Bolaki discusses the 'mixed genre' approaches used in contemporary texts from different ethnic traditions in America such as Chicano, AsianAmerican, African American, and Afro-Caribbean In accordance with the classical Bildungsroman, Bolaki also discusses the genre's basic element of the process of maturation:

The genre's movement from the uncertainty of youth to the power of maturity is often used to buttress Western ideas of progress and, as a result, more complex trajectories become assimilated into the familiar plot of generational conflict that the coming-of-age genre tries to resolve. (Bolaki, 2011: 11)

In her book, Bolaki examines a number of texts such as Jamaica Kincaid's At the Bottom of the River (1983), Sandra Cisneros's The House on Mango Street (1984), Maxine Hong Kingston's The Woman Warrior (1976), and Audre Lorde's Zami: A New Spelling of My Name against this rather traditional definition of the Bildungsroman. She looks at the possibilities in which the Bildungsroman can be used to "expose the traumas of a colonial education by decolonizing the self, or to illustrate the process of coming to voice for marginalized individuals and larger groups" (Ibid.). Related to Bolaki's argument of the formal properties of these texts is the way Balata designates her coming-of-age narrative to answer the 'generic box,' in this case the Bildungsroman, while at the same time takes into consideration the subject matter and thematic structure, that is, the intersection of her novel as a text of marginality with the Bildungsroman.

Through a strategic description of Kurdish history, culture and ideology, Balata dramatizes the love story of two university students from Duhok city against a cruel background of destructive war and exodus. Nareen is naturally headstrong and defiant. She is headstrong in speaking out against a culture that oppresses her. She is defiant in refusing to be defined according to the set standards and expectations of a gendered community. The story opens with worries of the up-coming war. It is 1990 and Saddam has invaded Kuwait and is threatened with a great war from the Coalition Forces if he refuses to 
withdraw. Expressing her deep worries and her anti-war sentiments and fear of its devastating effects on the people, Nareen tells her four female friends who share room number 4 in a student hostel on a campus at Mosul University about her previous experiences of war. She is sorry to have to stop her studies again and especially in the graduation year. Nareen narrates how she had to leave school in 1974 during the Kurdish Revolution against Baghdad when she was only six years old. Taking mountains as the only shelters from air raids, Nareen describes how they had to stay for whole days and nights with no food or drinks or medicines. She emphasises the importance of acquiring education and literacy even in times of war by adding that the teacher "would gather all of the school age children and teach us...the alphabet and some numbers orally because there were no books or notebooks" (34). For understanding Nareen's difficulties in getting formal education in a war-torn environment, Bolaki's argument is very illuminating. According to Bolaki, and in accordance with our earlier discussion of the process of maturation, in which education is crucial to the protagonist's movement from apprenticeship to journeymanship, "the school, as in early immigrant narratives and ethnic Bildungsroman, provides an early platform to excel in upward mobility skills" (Ibid.). Stating the examples of Kinciad and Kingston's novels of development, she further illustrates:

School enforces discipline and uniformity. The acquisition of literacy is an important stage in the slave narrative but often in the Bildungsroman, especially in the case of a postcolonial or ethnic American variant, formal education collides with the native culture and is used to fashion a colonial or an assimilated subject. (Ibid.)

Balata displays an influential adoption of narrational techniques through telling the story from different perspectives and points of view. Her novel, additionally, presents a vivid criticism of social aspects concerning women's subordinate roles, their restricted space of behaviour and their limited freedom and independence. The very simple act of visiting a friend or a relative arouses parental concern and investigation, as Balata shows that "in Kurdish culture, girls go out when there is a reason, for example to see a doctor and are occasionally allowed to visit friends and relatives by themselves so as not to disregard all rules of decent behaviour" (94). On one important occasion, Nareen ignores her mother's orders and decides to visit her friend Bafreen. Coming home she is met face-to-face with her father's anger and retribution. In an attempt to defend her rights, Nareen says she is "twenty-three years old, and I will graduate from college this year" (96), only to be given the most painful fact about her identity in an overly gendered society. Her father replies by saying she is 'still a woman' and that he "didn't send her to college so she can do whatever [she] thinks is right" (96).

A key element in Nareen's process of maturation is her need to expose and eradicate the social restrictions imposed on women by the patriarchal ideology of her society. In her tireless search for self-recognition, Nareen tries to set the impossible balance between her own desires and society's expectations of her as a female. Typical of the Bildungsroman, the story shows the gradual development of Nareen as a woman who comes to see the necessity of love and desire. She rhetorically asks her friend and neighbour Aishe, "[C]ouldn't I be in love and respect the tradition of our society at the same time?" (64) Nareen, who technically embodies the narrative voice in the novel and whose points of view imply Balata's own apparent authorial points of view, argues for the existence and identity of the woman as separate from the man. In defending her aunt Amina's right to get divorce from her husband who has taken a second wife, Nareen confirms that her aunt "is still a complete human being with or without her husband. She is a good person and mother, and her husband will never make her a better mother or human being" (80). The experiences of women in Kurdish society are highly affected by such cultural practises as polygamy, arranged traditional marriages and exchange marriages in which a man gives his sister, daughter or any woman in the family to another man as a wife in exchange for another woman from that man's family. These practices systematically support, underline and extend men's control over women. Nareen disapproves of such acts of inhumanity and oppression by refusing to marry Saman, her aunt Saffe's rich brother-in-law, saying 'No, I can't marry this way. I am sorry, Aunt Saffe' (78). Balata's work, as a text written from marginality illuminates the movement from an 'enforced silence' and subjectivity to 'coming to voice' and selfhood. 
Before moving to discuss Balata's creation of sites of female oppositionality and activism, it is important to remember that Kurdish novelistic discourse, particularly in Bahdinan, emerged substantially late compared to other parts of the world. This late emergence can be clearly linked to the stateless nature of the Kurdish people, the complex socio-political and cultural experiences of the Kurds in all the four states in which they live and the fragmented and complicated character of the Kurdish language and its many dialects. This late emergence has caused dire influences on the thematic and formal properties of the Kurdish novel which still suffers numerous complications in terms of its generic structure and composition. In her article "Kurdish Autobiography, Memoir and Novel: Ereb Shemo and His Successors" presented at a conference in Yerevan, Christine Allison, a specialist on Middle Eastern and popular cultures including Kurdish culture and oral literature, confirms the difficulty of drawing a clear line between autobiography and novel in the Kurdish context:

For the Kurdish context the usefulness of attempting a clear distinction between autobiography and novel seems limited; boundaries between autobiography and novel, like these between autobiography and memoire, are apt to be blurred. There is no a prior assumption by Kurdish novelists that the novel ought to be a work of fiction. (Allison, 2005: 102)

Allison further explains that most Kurdish novelists expand the 'autobiographical space' of their works to include "the story of their family or tribe or of their villages" (Ibid.). An important element of the Kurdish novel is its emphasis on the role and importance of the Kurdish individual with his own distinct historical and cultural features that differentiate him from the ones imposed on him by the controlling governments. In his book, Autumn of the Words: Critical and Thinking Studies, Sabri Silevani, a contemporary Kurdish writer and novelist, confirms this interest in the individual within the Kurdish novel and describes the need of the post-war modern Kurdish individual for knowledge and awareness of the world around. According to Silevani, "the modern Kurdish individual needs freedom of thought and action in order to achieve recognition" (Silevani, 2005: 134) Ereb's text and the texts of his successors, as direct antecedents of the contemporary Kurdish novel, are all narrated by
Kurdish individuals who recognize the internally and institutionally marginalized self and undergo on-going transformation.

\section{WOMEN COMING TOGETHER TO CHALLENGE MARGINALITY}

According to Felski, the public-sphere, originally theorized by the German sociologist and critical theorist Jürgen Habermas in Structural Changes in the Public Sphere, is a model that refers to a "historically determined formation which emerges from the specific conditions of late seventeenth- and eighteenth century society" (Felski, 1989: 165). Felski adds that the main participants of the public-sphere are "maleproperty owners and the enlightened aristocracy" (Ibid.). Defined as an area in social life where 'individuals can come together to freely discuss and identify problems and through that discussion influence political action" (Ibid.), the groups working within the contexts of the public spheres have taken forms of power and domination. Believing that economic, political and social action should be controlled and perpetuated by the public sphere, the dominant groups, accordingly, started to exploit the marginal groups and assume their inferiority and even, in some contexts, their complete exclusion. The marginalized groups are groups with a "deficiency in the economic, political, and social resources used to guarantee rights and privileges assumed by dominant group members" (Squires, 2002: 467).

The feminist movement, challenging the political structures and patriarchal beliefs and practices, has become an active form of resistance and oppositionality since its first emergence in the late nineteenth century. Considering such challenges as forces for change and transformation in social and political values, Felski proposes and defines the concept of a feminist counter-public sphere as a "model for the analysis of diverse forms of recent artistic and cultural activity by women in relation to the historical emergence of an influential oppositional ideology which seeks to challenge the existing reality of gender subordination" (Felski, 1989: 167). The feminist public sphere presents a critique of social, political, and cultural values from the point of view of women as a marginalized group within society. The feminist public sphere "constitutes a discursive arena which disseminates its arguments 
outward through such public communications as books, journals, the mass-media, and the education system" (Ibid). Thus, Felski asserts that feminist discourse originates from women's experiences of oppression. Such a claim is rightfully the case in Kurdish feminist movements. Throughout history, Kurdish pro-feminist movements have acted to generate a genderspecific identity through forming and developing an awareness of the importance of community and solidarity among women and have challenged, to use Felski's words, "to convince society as a whole of the validity of feminist claims, challenge existing structures of authority through political activity and theoretical critique" (Ibid.). Given this fact, to develop a Kurdish feminist counter-public sphere that can facilitate the ability of Kurdish women to freely discuss political and cultural issues of significance related to their positions as members of society will surely posit their struggle for gender equality and self-determination in a more official form. Formulating such criteria for a Kurdish feminist public sphere is indeed worthy both theoretically and practically since such feminist institutions do exist nowadays in the Kurdish society.

Given the long history of Kurdish resistance and national movements for national liberation, it is no surprise that the first political struggle for Kurdish women's emancipation coincide with the rise of nation and nationalism. According to Shahrzad Mojab in "Crossing the Boundaries of Nationalism: The Struggle for Kurdish Women's Studies," the first Kurdish women's organization, 'Society for the Advancement of Kurdish Women,' founded in 1919 in Istanbul by members of the Kurdish aristocracy in exile, "aimed at enlightening Kurdish women with modern thinking and promoting fundamental social reforms in the life of the family" (Ibid.). Though such organizations tried to develop consciousness and solidarity among women, they didn't make much progress since they were mainly dependent on the national organizations and movements which, as confirmed by Mojab, "relegated women's emancipation and class struggle to the future after achieving sovereignty" (Ibid.). Discussing the Kurdish women's need for selfdetermination, Susan MacDonald adopts a feminist approach to argue the possibility of such a necessity in the international law:
Today, some Kurdish nationalist movements have objectives that sound laudable: the restructuring of power, the creation of a society based on equality and non-exploitation, the freedoms of speech, religion, and association. Yet the feminist objective of change towards gender equality challenges is subsumed by the nationalist agenda. (McDonald, 2001: 147)

Accordingly, any Kurdish nationalist group that seeks independence and statehood should be able to seek and protect the fundamental civil rights of gender-equality and self-determination of its women. It should also allow them to have their own organizations and networks. It is only with such institutions that a Kurdish feminist sphere can be a working place of oppositionality. Such platforms are especially necessary for Kurdish women, since they are exposed to both an external war of genocide, linguicide, and ethnocide, and an internal war waged by male members of the Kurdish nation. The Kurdish feminist public sphere is actively engaged in locating:

The diverse forms of contemporary feminist literature and culture in relation to the contradictory tensions generated by the feminist public sphere, which simultaneously affirms and problematizes the very ideal of gendered reality that defines it. (Felski, 1989: 169)

Challenging the patriarchal politics of the Kurdish community, Balata draws the Kurdish women's resistance to all these forms of oppression. Runaway to Nowhere depicts Nareen and her female friends and relatives exposed to various forms of oppression from the Iraqi government on the one hand, and the patriarchal Kurdish community on the other. This oppression becomes more overt through Nareen's experiences during the 1991 Kurdish mass-exodus. In 1991, the Gulf War created a power vacuum that led to an Uprising of the Kurds guided by the Kurdish freedom fighters (the Peshmerge) as well as the Kurdish collaborators and the common people. After being informed that the U.S will stay neutral, the Kurdish people recognized that their revolt will carry bad consequences; therefore, they started preparing for an escape fearing from possible chemical attacks by the Iraqi army. Nareen's family leaves the city afoot towards the frozen Turkish mountains until some truck stops to carry people. Here, the story takes a new turn as Nareen is separated from her parents together with her only six year old brother when the kids make 
it inside the truck while the parents don't. Realizing it is no point waiting for her parents on the roads in Amediye, Nareen decides to follow the crowd in their path to the refugee camps along the Turkish border. Their way through the wilderness and mountains is a crucial test for Nareen, who suffers with her brother from cold, hunger, exhaustion, and diseases. The narration provides tens of examples explaining this massive ordeal: "The people walking to the Turkish border were exhausted, hopeless, and miserable. Everybody looked aged...many people were holding sick and elderly relations on their backs and were sweating under their loads. The blind and the crippled were falling down" (244).

After writing prolifically about Nareen's journey towards the Turkish mountains, the narrative moves to detailed descriptions of the camp itself. The camp is sprawled across the valley with nearly 200,000 tents laid out in chaotic grids to house the Kurds in their mass-exodus. Once arriving at the camp, Nareen notices that the conditions are no better than on the roads as "people were desperate with sickness and many were close to death" (178). In the camp "the smell of diarrhea has filled the air" (178). Survival and death become the controlling forces that occupy Nareen's thoughts. We are told that 'every morning the moans of women crying for their children were the first sounds heard in the camp' (184). Living these terrible images, spending days and nights in the open freezing wilderness, walking in rain and snow with her sick brother on her back, Nareen's eyes are opened to a new reality about life, about the world and most importantly about herself. Against the horrible images of sickness and death, we hear words such as love, strength, and survival. Nareen, who remembers Karwan telling her "life is never easy and we have to work hard to survive" (154), uses love as a way to escape her harsh reality. Nareen finds in love the shelter that protects her from the war and its devastating effects, and the motivation to go on. Whenever in trouble, cold, hungry, or tired, she remembers Karwan asking her to "be strong and work according to the situation and she will say to herself, I promise you Karwan I will stay strong" (138). This determination to stay strong and survive is a pivotal stage in Nareen's personal transformation.

As a text written from marginality, Balata's Runaway to Nowhere offers the notes and perceptions of a subject not only caught by forces of a destructive war that threatens her physical safety, but a female subject caught in a terribly male-defined environment. In the camp, Nareen meets and befriends a number of women whose family members share values that promote patriarchal beliefs. An important stereotypical example is Shukria whose baby dies like hundreds other babies due to extreme cold, malnutrition and diseases. Two days after her baby's death, Nareen hears Shukria's loud screams and fists hitting her body coming from inside the tent. It is her fatherin-law, Ibrahim, beating her because she has told him that her baby's death is his fault. As a food representative, Ibrahim keeps stealing food and selling it for money. So, Shukria tells him he is a sinner and God has punished their family by taking the soul of her baby. Though Shukria's husband disapproves of his father's acts, he can't stop him since in the Kurdish society the older man represents the supreme authority and his acts and decisions can never be questioned or refused. Another important example is Mayan, Nareen's other neighbour. Missing her parents, Nareen asks Mayan whether she misses her parents too. Married for almost a year and a half, Mayan replies saying that her mother has passed away four years ago and that she hates her father so she doesn't care about him. Nareen doesn't get puzzled after knowing that her father has forced her into a sad unhealthy marriage to an old man in exchange with that man's daughter: "My stepmother is my husband's daughter. I married her father, and she married my father. I'm eighteen-years old and my husband is forty-eight. My stepmother is seventeen and my father is fiftyone" (181).

Mayan's exchange marriage, very frequent in the Kurdish society, shows to what extent such a marriage can destroy a woman's dreams of love and happy living. She describes how miserable her married life is and how "ever since the first day, any time [my husband] touches me, I think of my father. And then, I become sick and throw up" (188). Mayan, of course, doesn't consider divorce since as it is traditional in exchange marriages if she divorces, her father will have to divorce his wife as well. Nareen feels angry and very sad for Mayan and wishes there was something she could do for her. These experiences enhance Nareen's awakening and understanding of the subordinate positions of the women in her society and 
strengthen her disapproval of such acts of oppression and inhumanity. According to MacDonald, women share "a collective social history of disempowerment, exploitation and subordination, extending to the present" (McDonald, 2001: 141). Therefore, any Kurdish feminist literature as a form of action within the feminist public sphere must be reoriented to reflect and respond to the many levels of oppression in the international community and as a start; women's voices must be heard in local, national and international levels.

In line with Felski's characterization of the feminist Bildungsroman, Balata employs the recurring motif of community to establish an alternative framework for her female characters' resistance and survival. In her discussion of the importance of community in the feminist Bildungsroman as a realist narrative of female emancipation, Felski contends that "the model of female community offers an alternative form of intimacy grounded in gender identification" (Felski, 1989: 132). She further argues that community is "perceived to complement and extend the protagonist's sense of self rather than to threaten it by absolute otherness, and thus to provide a framework within which a gendered identity can be meaningfully located" (Ibid.).

In the refugee camp and despite her terrible conditions, Nareen looks for her friends and manages to meet both Bafreen and Jihan. Nareen meets Jihan in the camp clinic where Nareen volunteers to work as an interpreter after finding her parents. Nareen learns that Jihan's sons are very sick with diarrhoea and they are not likely to make it. Nareen goes to visit them in their tent and is shocked to learn that her sons have both died. She feels very sad as she watches Jihan "screaming and beating her head and chest...she tried to kiss and calm her, but the burn in Jihan's heart was too painful...Jihan was jumping and beating her chest inside the tent and nobody could stop her" (217-218). A few days later, Nareen goes with Bafreen to see Jihan who now looks like an old lady; "with her back bent and her eyes red and swollen" (222). Living these painful moments, the friends "hugged and put their heads together and cried for a long time" (222). Though they cannot change the horrible reality, Nareen and her friends realize that survival and determination are only achieved through solidarity and interdependence.
Runaway to Nowhere shows that unity between the characters' psyches and the social world strengthens both their individual identities and their communal awareness and presents different stages of community through which Nareen goes realizing that women's interdependence is the key to resistance and self-determination: "Kurdish women are always affectionate to each other. They help each other and make friendships with one another very easily despite differences in age, education, and tribe" (181). The first community she experiences is with her four friends in the university. Their friendship is based on mutual love and co-operation as they listen to each other and give advice whenever needed. Against the horrible news of the war, Balata sets the moments of love and intimacy in room 4 they call Paradise: "They gathered to sit around the oil heater together one last time. Thinking quietly, they each felt their emotions and thoughts storming in their minds the way rain hit a tree" (39).

\section{GENDER AND NATIONALITY: NAREEN'S STORY AS AN ALLEGORY}

Though most researches and studies of Kurdology compare the oppression of women in the Kurdish community to the national oppression of Kurdistan, gender has often been ignored and treated as a secondary issue to be dealt with, if ever, once national liberation is achieved. Related to this fact is Susan MacDonald's argument of Kurdish women and self-determination:

The women's organizations that do exist are not independent from the political parties with which they are affiliated. Indeed, the women's organizations are most often extensions of the parties' platforms in which parties jostle to gain women's votes. While there are few women in leadership roles, of great significance is the dearth of feminist consciousness among the Kurdish women. (McDonald, 2001: 141)

Throughout her research, Mojab refers to the 'dearth' of feminist consciousness among Kurdish women. First, the status of the Kurds as a stateless nation and the division of their homeland among different countries has worked against developing an awareness of solidarity. Second, there has been an absence of a gender dimension in the few academic researches and studies that deal with the Kurds, their history and their culture. Mojab further indicates that "the literature produced by 
Kurdish women's groups or Kurdish political organizations, in particular in Iraq and Turkey has focused more on two aspects of women and war: women as war causalities and women as war refugees" (Ibid.).

While it is true that death and immigration are the most direct and destructive consequences of war, it actually affects women's life in more than these two ways. Runaway to Nowhere describes women as victimized not only by the restrictive patriarchal values of the Kurdish society, but by their cruel war-torn world. Yet women have historically survived oppression through developing mutual love and support. In the novel, Nareen expands her discussion of the sufferings of women not only in her gendered but highly racial environment by calling into question the historical case of the Kurdish people as she asks Karwan, her lover, "why were we born Kurdish? Why are we not from a peaceful place, so we could enjoy our life far from all this trouble?" (122) The novel shows that Nareen's suffering as a Kurdish woman is a part of her suffering as a Kurdish individual. Balata makes constant references to the complex political atmosphere that surrounds the characters' daily life. Nareen has always experienced wars and migrations as a result of the continuous struggle between the Kurdish nationalist movements and the $\mathrm{Ba}$ 'ath regime. The reader is constantly urged to see the inner conflicts of Nareen in relation to the outer circumstances as her familial life, education and love are all directly affected by the political struggle of her people.

Though many readers prefer to see the novel as a love story between Nareen and Karwan, the novel contains numerous political gestures and depicts the ways love intersects with wars and escapes. Balata shows this in her preface to the novel saying that "their love story crosses the path of the first Gulf war and all the subsequent events" (11). An example of the political struggle is the Ba'ath's prohibition of Nawroz, the Kurdish New Year. When the Kurdish students in Mosul University gather to celebrate Nawroz, the security men cut the electricity not allowing the celebration to start. As Nareen shows her resentment of such oppression, Balata confirms this is not the first time:

It had happened on many other occasions when the security people bothered the Kurdish students. Sometimes the students responded with protests. Saddam's security men arrested a large number of put them in jails, and tortured them. Many students executed or killed by overly-eager torturers, never returned from the prisons. Those who came back were weak from the torture and traumatized. It was the world they lived in, the world ruled by Saddam Hussein and those before him who kept the Kurds oppressed and silent. (26)

All the characters in the novel fall victims to the political struggle and the wars that permeate and affect their entire life whether directly or indirectly. At the start of the novel, Kurdish people suffer from the UN sanctions on Iraq resulted from Saddam's invasion of Kuwait. Shortly after the war starts people suffer from continuous air raids and bombings and many people are killed after few nights of airstrikes. The political references continue through the Kurds' Uprising against the Ba'ath regime and the subsequent mass-exodus after the failure of the Uprising. In the camp, Nareen befriends an American female journalist, Emily, who asks Nareen about the life of the Kurdish women and the policy of assimilation that the Kurds suffer under the brutal regime of Saddam Hussein. Nareen tells Emily that she was very young when she realized that the Iraqi government was abusing the Kurds. She remembers her father coming from the tea house saying:

The government's security men came to the tea house and told everybody there from now on, the Kurdish people were not allowed to name their children and their shops Kurdish names. Instead they must use Arabic names. And, if anybody wore Kurdish clothes outside the house, they would be jailed. (225)

The intersection and tension of the categories of the personal and the national aspects of Nareen's life continue until the very end of the novel when Nareen states her wishes and dreams to Emily saying that her wishes are, 'in general, a united Kurdish state - a wish that will continue to live in my heart and the hearts of millions of Kurds across the globe. And personally, I wish to find Karwan soon and get married and have four children" (233). Runaway to Nowhere dramatizes the tensions between personal and public identity, between private emotional commitment and public communal expectations. Balata attempts to formulate a new understanding of collective public life. Therefore, it can be safely argued that the novel has political in addition to aesthetic motivations with Balata creating a vehicle through 
which to consider the possibilities of arranging their narrative elements in a way that best subvert the traditionally existed and identified genre of the Bildungsroman to elaborate their national aspirations.

By the concluding pages of the novel, Nareen's awareness of her personal development takes another important form when she asks her parents after finding them, to allow her to help the people working in the camp clinic as an interpreter since she speaks English. The narrative gives details of Nareen's first day at the clinic describing how painful it is for Nareen to see the long line of sick and injured people with not enough doctors or medication. She finds that "many little babies were so dehydrated that they were unlikely to last the night...Nareen felt very depressed after her first day working there" (214-15). On her way home, Nareen keeps thinking of the dying people at the clinic and angrily asks within herself "will anybody ever save us? Are we not human beings?' (215) In Lorde's words in Sister Outsider, for a woman "anger becomes the life force that allows her to survive to assert her own existence in the face of an oppression that demands silence and servitude" (Lorde, 1984: 127). After the establishment of the no-fly zone in the north of Iraq, people were allowed to return to 'a Saddamfree Kurdistan.' Nareen, like all the Kurdish people in the refugee camps, thinks it is "too good to be true" (233). With six other families, Nareen's family rent a truck and start their journey back to their "beautiful city Duhok" (239).

It is very important to mention that Balata's novel concludes by showing that Nareen eventually discovers what it is that she really wants, and triumphantly reinters the society in which she was born. Nareen comes back from death; from loss, from nowhere understanding the importance of communal interdependence. Though she finds out that Karwan has been killed defending the city against Saddam's army and Nareen, succumbs for some time to tears and sadness and even considers ideas of suicide, she, nevertheless, remembers the promise she has made and decides to go on. The novel ends with an emphasis on the necessity of solidarity as part of women's political organization and gendered identity. In the prologue and after ten years, we read about Nareen and her four friends gathered at Bafreen's house all acknowledging their strength to have "survived all that sadness" (204). Nareen, now an active member in the Kurdish Women's Centre directed by her friend Buhar, describes how proud she is to help women in need, to teach them literacy and help guarantee "their legal rights, health issues, and employment" (264). The narration closes with Nareen visiting Karwan's grave promising never to forget him, celebrating her personal freedom and independence, and wishing, in a most self-reconciling moment that "no one had to go through what we had went through" (269). This deviation from the happyever-after ending of the traditional Bildungsroman further complicates the reader's perceptions of the text's ending as one comes to ask himself/herself how Nareen is envisaged in relation to her highly ethnic and gendered society.

\section{CONCLUSION}

By linking the collective socio-political and cultural situations of her society to the experiences of Nareen, Balata suggests that Kurdish women should be seen as part of Kurdish history and the nationalist movement for liberation. As exemplified by Runaway to Nowhere, Kurdish women writers not only depict women's concerns but they politicize such concerns to address the interlocking nature of ethnic, sex, and class oppression. They bring women's marginalized voices to the centre, confirming that women need to create counter-public spheres that better represent their changing needs and desires. Focusing almost exclusively on female characters, the novel suggests that women's solidarity and communal affinity are the means by which to redirect attention to women's changing roles and perceptions, and thereby intervene in history. Informed by studies that integrate literary and social theory, particularly the work of Felski and Bolaki, the study has investigated the transformational trajectories of a female protagonist from a silenced victim to resilient activist, in other words, the multi-layered mechanisms she develops to resist violence and subjugation.

\section{NOTES}

${ }^{1}$ Born in 1968 in Duhok city, the capital of Duhok Governorate in the Kurdish Region, Balata has witnessed many of the challenges faced by the Kurdish people in Iraq. After completing a B. A. degree in 
translation from the University of Mosul, Balata wrote and translated various articles for Mateen magazine and worked for two years as a news-editor and translator for Kabat TV in Duhok. In 1995, Balata started working for an American organization, Office of Foreign Disaster Assistance, OFDA and migrated with her family to Boston, USA shortly after that. After getting an M. Ed from Cambridge College in Boston, she moved back in 2007 to settle in Iraqi Kurdistan where she is still teaching English language at the University of Duhok.

${ }^{2}$ In 1987 Saddam Hussein feared the collaboration of the joint Kurdish forces (KDP and PUK) with Iran to which he responded by appointing his cousin Hassan Ali Al-Majid. Al-Majid was given absolute power and command over all "intelligence agencies, including military intelligence (al-Istikhbarat), and all domestic security forces, including the Popular Army Command (Qiyadat al-Jaysh al-Sha'bi) and the military commands in the northern region" (Yildiz, 2004, 2526). He commenced his military administration by creating a war-zone that was by 1989 thirty kilometres wide, including most of the strategic Kurdish towns and villages. He started a series of operations of Kurdish village mass-destruction, relocation and ethnic cleansing.

${ }^{3}$ All further references to this work will be cited in the text by page number in parentheses.

\section{REFERENCES}

- Allison, Ch. (2005) Kurdish Autobiography, Memoir and Novel: Ereb Shemo and His Successors. Studies on Persianate Societies, Vol.109, No.4, 97-118.

- Balata, Q. (2010). Runaway to Nowhere. Utah: Beside Books, American Publishing House.

-Boes, T. (2012). Formative Fictions: Nationalism, Cosmopolitanism, and the Bildungsroman. New York: Cornell University Press.

-Bolaki, S. (2011). Unsettling the Bildungsroman: Reading Contemporary Ethnic American Women's Fiction. New York: Amsterda-New York.

-Felski, R. (1989). Beyond Feminist Aesthetic: Feminist Literature and Social Change. London: Hutchinson.

- Kester, G. T. (1997). Writing the Subject: Bildung and the African American Text. New York: Peter Lang Publishing.

-Lorde, A. (1982). Zami: A New Spelling of My Name. New York: The Crossing Press.

----, L. (1984). Sister Ousider. New York: The Crossing Press.

- McDonald, S. (2001). Kurdish Women and Selfdetermination: A Feminist Approach to
International Law. Women of a Non-State Nation: The Kurds, Vol. 7, 135-157.

-Mojab, Sh. (1997). Crossing the Boundaries of Nationalism, Patriarchy, and Eurocentrism: The Struggle for a Kurdish Women's Studies Network. Canadian Woman Studies, Vol. 17, 68-72.

-Mustafa, Gh. (2013). When Mountains Weep: Coming of Age in Kurdistan. Duhok, Gharbi Mustafa.

-Silevani, S. (2005). Payiza Peyvan: Xwandnên Hizri $u$ Rexneyi, (Autumn of Words: Critical and Thinking Studies). Duhok: Kurdish Writers' Union.

-Squires, R. (2002). Rethinking the Black Public Sphere: An Alternative Vocabulary for Multiple Public Sphere. Communication Theory, Vol. 12, No. 4, 446-468.

\section{Personal Interview}

- Balata, 17 November 2016, Personal Interview 